\title{
INTESTINAL PARASITIC INFECTION IN EGYPTIAN CHILDREN: COULD IT BE A RISK FACTOR FOR IRON DEFICIENCY ANEMIA? \\ By \\ ZEZE TH. ATWA ${ }^{1 *}$ and MARWA M THABET ${ }^{2}$
}

Department of Pediatrics, Faculty of Medicine ${ }^{1}$, and Department of Parasitology, Faculty of Science, Fayoum University ${ }^{1,2}$, Fayoum Governorate, Egypt

(*correspondence: ztm11@fayoum.edu.eg, Mobile: 00201005323134)

\begin{abstract}
A case control study that associates IDA with different parasitic infections and socioeconomic factors. The study enrolled 194 children with IDA and 180 age matched control. Patients diagnosed as IDA by complete blood count (CBC), and iron indices. All cases were subjected to complete history, anthropometric measures, and $\mathrm{CBC}$ and stool analysis. Ancylostoma duodenal, Ascaris lumbercoides and Giardia lamblia infections, lower family income, increased number of family members and eating meat in low frequency could be independent risk factors for IDA as detected by multivariate regression analysis. A. duodenale and $G$. lamblia were associated with lower ferritin levels in anemic patients. No significant associations as regards residence, body mass index, mother employment or education levels $(p>0.05)$.

Keywords: Iron deficiency anemia, Parasites, Socioeconomic.
\end{abstract}

\section{Introduction}

Iron (Fe) deficiency anemia (IDA) is a significant public health problem as it is the most common cause of anemia all over the world. About $40-50 \%$ of children are iron deficient in developing countries (UNICEF, 2002). In Egypt, the prevalence rates of IDA were $43 \%$ of children aged 6-24 months (Elalfy et al, 2012) and $25.6 \%$ of those aged 6-11years (Abdel-Rasoul et al, 2015). Iron is an important element for brain growth and development especially during infancy as it is required for several functions in the brain including nerve fiber myelination and acting as a cofactor in several reactions for neurotransmitter synthesis accordingly cognitive dysfunction is a major consequence of iron deficiency (Rao and Georgieff, 2001). Reduced work capacity is additional consequence of iron deficiency (Haas and Brownlie, 2001). IDA in African children has numerous risk factors which illustrates the complex etiology (WHO, 2008). Inadequate nutritional iron intakes, insufficient absorption of iron, and iron loss by bleeding are the main causes of IDA. Bleeding may be via intestinal, urinary tract or uterine route. Parasitic infestation may be a cause irondeficiency anemia in children as a result of mal absorption and intestinal bleeding caused by the worm, which may be nonnoticeable in feces (Calis, 2008).

Parasitic infections are considered a major public health problem especially in developing countries. Globally intestinal parasitic infections were predicted in about 3.5 billion people, the great majority were children (Brooker et al, 2009). Parasitosis resulted in poor growth, physical weakness, decrease in educational performance and other morbidities (Nokes, 1994). Intestinal parasites such as amoebiasis, ancylotsomiasis, trichiuriasis and ascariasis were considered the commonest distributed parasites worldwide (WHO, 1987). The main causes of iron deficiency anemia should be investigated using various interventions that based on clinical and epidemiological information.

This work aimed to study the effect of common intestinal parasitosis and triggering iron deficiency anemia, in relation to sociodemographic and economic factors of children attending Al-Fayoum University Pediatrics Hospital.

\section{Subjects, Materials and Methods}

Study design and setting: A case control study was carried out on 194 patients with IDA and 180 ages matched healthy controls at the time from May2016 to September 2016 in outpatient clinic of Al-Fayoum Uni- 
versity Pediatrics Hospital. Inclusion criteria were children aged 2 to 12 years old diagnosed as IDA by CBC, serum ferritin, serum iron, total iron binding capacity. Control group included cross ma-tched children with normal CBC (normal he-moglobin and other hematological indices). Exclusion criteria were children less than 2 years, more than 12 years with associated chronic disease,

All cases and controls were subjected to full history taking including age, sex, residence, mother education and employment, family members per house, family income, and average frequency of eating meat per week. Weight and heights were obtained using appropriate calibrated devices, and then BMIs were calculated

Laboratory examination: Aseptic venous blood samples were collected and examined for hematocrit value, hemoglobin concentration, erythrocyte indices as mean corpuscular $\mathrm{Hb} \quad(\mathrm{MCH}), \mathrm{MCH}$ concentration (MCHC), corpuscular volume (MCV), and red cell diameter width (RDW). The complete blood count (CBC) was done using Coulter 1660 to determine the $\mathrm{MCH}, \mathrm{MCV}$ and RDW. Anemia was identified by $\mathrm{Hb}$ concentration below the adjusted values for age groups (Wonke et al, 2007). Microcytosis and hypochromia were diagnosed when the MCV was below $80 \mathrm{fl}$ and $\mathrm{MCH}$ below 27 pg. (Johnson-Wimbley, 2011).

Anemic children were subjected to: Serum ferritin measure using Immulite/Immulite 1000 ferritin kits (Siemens, Los Angeles, California), serum iron levels, total iron binding capacity (TIBC) using calorimetric kits (Stanibo Co., USA). Transferrin saturation was calculated as serum iron divided by TIBC. Iron diagnostic for IDA consisted of a low $\mathrm{Hb}$ for age, together a low SF with below $12 \mu \mathrm{g} / \mathrm{L}$ or low TS below $16 \%$ (Johnson-Wimbley, 2011). Hb electropho-resis was done to exclude $\beta$ thalassemia minor (Eden and Sandoval, 2012). .

Fecal samples were collected in dry plastic labeled container and examined macroscopically for color, consistency, pin warms, lar- vae, blood and mucous. Direct wet smear methods using iodine and lacto-phenol cotton blue and concentration technique were used to examine fecal sample (El-Naggar et $a l, 2006)$. Formalin-ethyl acetate sedimentation was done and examined by direct wet smear using Modified Ziehl-Neelsen stain for cryptosporidiosis (Garcia, 2007).

Ethical consideration: Protocol was approved by the ethical committee of Faculty of Medicine, Al-Fayoum University. Informed oral consent was obtained from each child's parents before participation in the study.

Statistical analysis: Data was collected and coded to facilitate data manipulation and double entered into Microsoft Access and data analysis was performed using SPSS software version 18 under windows 7. Simple descriptive analysis in the form of numbers and percentages for qualitative data, and arithmetic means as central tendency measurement, standard deviations as measure of dispersion for quantitative parametric data, and inferential statistic test: Independed student t-Test used to compare measures of two independent groups of quantitative data. One way ANOVA test was used to compare more than two independent groups of quantitative data and Chi square test to compare two of more than two qualitative groups. Multiple linear regressions tested association between quantitative dependent and in-dependent variables and detection of risk factors. The $P \leq 0.05$ was considered cut-off value for significance.

\section{Results}

The study included 194 patients with iron deficiency anemia. Mean age of study patients was $(6.5 \pm 3.5$ years $)$, the mean HB level was $(8.3 \pm 1.2 \mathrm{~g} / \mathrm{dl})$. Mean $\mathrm{MCV}$ was $(67.7 \pm 8.4 \mathrm{fL})$, mean $\mathrm{MCH}$ was $(23.4 \pm 3.6 \mathrm{pg})$ and mean RDW was $(18.36 \pm 1.27)$. Mean serum ferritin level was $(10.93 \pm 2.78 \mu \mathrm{g} / \mathrm{l})$ and mean TIBC was $(405.5 \pm 55.6 \mu \mathrm{g} / \mathrm{dL})$. $55.7 \%$ of patients are resident in rural area and $44.3 \%$ were from urban areas. As regards mother's employment level around 
$69.1 \%$ of mothers were non workers. Prevalence of parasitic infection was $17.5 \%, 33 \%$, $38.1 \%$ \& $18 \%$ with hookworm, A. lumbricoides, E. vermicularis and $H$. nana respectively. Giardia lamblia and E. histolytica was found in $25.8 \%$ \& $33 \%$ of patients respectively.

Infection with $A$. duodenale, A. lumbricoides and G. lamblia were significantly associated with IDA as they were presented with higher frequency in anemic patients. No significant differences between anemic and control as regards infection with $H$. nana, E. vermecularis or $E$. histolytica. Intestinal infection with $A$. duodenale and $G$. lamblia were significantly associated with lower ferritin levels in anemic patients (P-value 0.01 $\& 0.03$ respectively), without significant associations with serum ferritin as regards other parasites. Mean ages were 6.6 \pm 3.5 years \& $7.4 \pm 3.2$ for patients and control respectively without significance differences $(\mathrm{P}=0.15)$. No differences were found between patients and controls regarding sex, residence or mother work. Monthly income less than 1200 LE was found in higher percentage among patients with iron deficiency anemia (p. value $=0.000$ ).

There was a significant difference between patients and controls as regards number of family members/house, family size less than 5 was associated with less frequent IDA compared with those with more than 5 members $(\mathrm{P}=0.001)$. There was also a significant difference between patients and control as regards Frequency of eating animal meat per week, eating meat less than 2 times per week was significantly associated with more frequent IDA $(\mathrm{P}=0.000)$. No significance differences between patients and control was found as regards level of mother education or BMI.

The multivariate linear regression model analysis illustrated significance predictors with $\mathrm{p}$-value $<0.05$ to family income, frequency of eating meat, number of family members/house $(\mathrm{P}=0.00,0.00 \& 0.002$ respectively), infection with $A$. lumbricoides, $A$. duodenale and/or G. lamblia were significance predictors $(\mathrm{P}=0.004,0.017$ and 0.014 respectively). Details were given in tables $(1,2,3,4,5 \& 6)$.

Table 1: Clinical and socio-demographic characters of anemic patients.

\begin{tabular}{|l|c|c|}
\hline Variables & Number $(\mathrm{n}=194)$ & $\%$ \\
\hline Male & 110 & $56.7 \%$ \\
\hline Female & 84 & $43.3 \%$ \\
\hline Body mass index Percentile: $>3^{\text {rd }}<95^{\mathrm{TH}}$ & 114 & $58.7 \%$ \\
\hline Below 3 & 62 & $32 \%$ \\
\hline Above 95th & 18 & $9.3 \%$ \\
\hline Residence:Rural & 108 & $55.7 \%$ \\
\hline Urban & 86 & $44.3 \%$ \\
\hline Mother education level Illiterate & 48 & $24.7 \%$ \\
\hline Primary & 67 & $34.6 \%$ \\
\hline Middle level & 58 & $29.9 \%$ \\
\hline High education & 21 & $10.8 \%$ \\
\hline Mother employment Worker & 60 & $30.9 \%$ \\
\hline Non worker & 134 & $69.1 \%$ \\
\hline Family members: $\leq 5$ & 76 & $39.2 \%$ \\
\hline$>5$ & 118 & $60.8 \%$ \\
\hline \multicolumn{2}{|c|}{ Parasitic infestation } & $17.5 \%$ \\
\hline Hookworm & 34 & $33 \%$ \\
\hline Ascaris lumbercoides & 64 & $38.1 \%$ \\
\hline Enterobius vermicularis & 74 & $18 \%$ \\
\hline Hymenolepis nana & 35 & $25.8 \%$ \\
\hline Giardia lamblia & 50 & $33 \%$ \\
\hline Entameba histolytica & 64 & \\
\hline & \multicolumn{2}{|c|}{} \\
\hline
\end{tabular}


Table 2: Comparison between patients and control as regards intestinal parasitic infection

\begin{tabular}{|c|c|c|c|c|}
\hline Variable & Mean $\mathrm{hb} \pm \mathrm{SD}(\mathrm{g} / \mathrm{dl})$ & Frequency in 194 patients $(\%)$ & Frequency in 180 control (\%) & P. value \\
\hline $\begin{array}{l}\text { Hook worm +ve } \\
\text { Hook worm -ve }\end{array}$ & $\begin{array}{c}8.6 \pm 2.3 \\
10.6 \pm 2.4\end{array}$ & $\begin{array}{c}34(17.5) \\
160(82.5)\end{array}$ & $\begin{array}{c}10(5.6) \\
170(94.4)\end{array}$ & 0.000 \\
\hline $\begin{array}{l}\text { Ascaris }+\mathrm{ve} \\
\text { Ascaris -ve }\end{array}$ & $\begin{array}{c}9.6 \pm 2.4 \\
10.7 \pm 2.5\end{array}$ & $\begin{array}{c}64(33) \\
130(67)\end{array}$ & $\begin{array}{c}32(17.8) \\
148(82.2)\end{array}$ & 0.001 \\
\hline $\begin{array}{l}\text { Enterobius +ve } \\
\text { Enterobius -ve }\end{array}$ & $\begin{array}{l}10.3 \pm 2.6 \\
10.5 \pm 2.4\end{array}$ & $\begin{array}{c}74(38.1) \\
120(61.9)\end{array}$ & $\begin{array}{c}68(37.8) \\
112(62.2)\end{array}$ & 0.5 \\
\hline $\begin{array}{l}\text { H. nana }+\mathrm{ve} \\
\text { H. nana }-\mathrm{ve}\end{array}$ & $\begin{array}{c}9.9 \pm 2.3 \\
10.5 \pm 2.5 \\
\end{array}$ & $\begin{array}{c}35(18) \\
159(82) \\
\end{array}$ & $\begin{array}{c}22(12.2) \\
158(87.8) \\
\end{array}$ & 0.077 \\
\hline $\begin{array}{l}\text { Giardia }+\mathrm{ve} \\
\text { Giardia -ve }\end{array}$ & $\begin{array}{c}9.7 \pm 2.2 \\
10.6 \pm 2.4\end{array}$ & $\begin{array}{c}50(25.8) \\
144(74.2)\end{array}$ & $\begin{array}{c}24(13.3) \\
156(86.7)\end{array}$ & 0.002 \\
\hline $\begin{array}{l}\text { Entameba }+\mathrm{ve} \\
\text { Entameba }-\mathrm{ve}\end{array}$ & $\begin{array}{l}10.5 \pm 2.5 \\
10.4 \pm 2.4\end{array}$ & $\begin{array}{c}64(33) \\
130(67)\end{array}$ & $\begin{array}{c}64(35.6) \\
116(64.4)\end{array}$ & 0.34 \\
\hline
\end{tabular}

Table 3: Effect of parasites on ferritin level in patients with iron deficiency anemia

\begin{tabular}{|l|c|c|c|c|}
\hline \multicolumn{2}{|c|}{ Variable } & Mean ferritin \pm SD & F & P. value \\
\hline Hook worm & Yes & $9.83 \pm 2.82$ & 6.59 & $\mathbf{0 . 0 1}$ \\
\cline { 2 - 3 } & No & $11.16 \pm 2.72$ & & \\
\hline \multirow{2}{*}{ A. lumcricoides } & Yes & $10.62 \pm 3.23$ & 1.23 & 0.27 \\
\cline { 2 - 3 } & No & $11.08 \pm 2.52$ & & \\
\hline \multirow{2}{*}{ E. vermicularis } & Yes & $10.62 \pm 2.57$ & 1.5 & 0.23 \\
\cline { 2 - 3 } & No & $11.12 \pm 2.89$ & & \\
\hline \multirow{2}{*}{ G. lamblia } & Yes & $10.43 \pm 2.48$ & 1.5 & 0.21 \\
\cline { 2 - 3 } & No & $11.1 \pm 2.8$ & & \\
\hline \multirow{2}{*}{ E. histolytica } & Yes & $10.2 \pm 2.5$ & 0.032 \\
\cline { 2 - 3 } & No & $11.2 \pm 2.8$ & \\
\cline { 2 - 3 } & Yes & $10.8 \pm 2.35$ & & 0.64 \\
\hline
\end{tabular}

Table 4: Comparison of socio demographic parameters between IDA patients and control

\begin{tabular}{|c|c|c|c|c|}
\hline \multicolumn{2}{|c|}{ Variable } & Frequency in 194 patients $(\%)$ & Frequency in 180 control $(\%)$ & P. value \\
\hline \multirow[t]{2}{*}{ Sex } & Male & $110(56.7)$ & $105(85.3)$ & \multirow[t]{2}{*}{0.45} \\
\hline & Female & $84(43.3)$ & $75(41.7)$ & \\
\hline \multirow[t]{2}{*}{ Residence } & Rural & $108(55.7)$ & $93(51.7)$ & \multirow[t]{2}{*}{0.21} \\
\hline & Urban & $86(44.3)$ & $87(48.3)$ & \\
\hline \multirow{2}{*}{$\begin{array}{l}\text { Mother } \\
\text { work }\end{array}$} & Yes & $60(30.9)$ & $68(37.8)$ & \multirow[t]{2}{*}{0.2} \\
\hline & No & $134(69.1)$ & $112(62.2)$ & \\
\hline \multirow[t]{2}{*}{ Income } & $>1200 \mathrm{LE}$ & $74(38.1)$ & $104(57.8)$ & \multirow[t]{2}{*}{0.000} \\
\hline & $<1200 \mathrm{LE}$ & $120(61.9)$ & $76(42.2)$ & \\
\hline
\end{tabular}

Table 5: Multiple comparisons of some socio-demographic parameters between IDA patients and control

\begin{tabular}{|c|c|c|c|c|c|}
\hline Variable & Multiple comparison & $95 \%$ Confidence Interval & P. value & $\mathrm{F}$ & P. value \\
\hline \multirow{3}{*}{$\begin{array}{l}\text { Family members/ } \\
\text { house }\end{array}$} & $\leq 5$ versus $>5<7$ & $0.046,0.262$ & 0.005 & \multirow[t]{3}{*}{7.37} & \multirow[t]{3}{*}{0.001} \\
\hline & $\leq 5$ versus $\geq 7$ & $0.120,0.422$ & 0.000 & & \\
\hline & $>5<7$ versus $\geq 7$ & $-0.036,0.275$ & 0.13 & & \\
\hline \multirow{3}{*}{$\begin{array}{l}\text { Consumption of } \\
\text { meat/week }\end{array}$} & $\leq 2$ versus $>2<5$ & $-0.360,-0.150$ & 0.000 & \multirow[t]{3}{*}{15.12} & \multirow[t]{3}{*}{0.000} \\
\hline & $\leq 2$ versus $\geq 5$ & $-0.499,-0.162$ & 0.000 & & \\
\hline & $>2<5$ versus $\geq 5$ & $-0.249,0.098$ & 0.39 & & \\
\hline \multirow{3}{*}{$\begin{array}{l}\text { Level of mother } \\
\text { education }\end{array}$} & Illiterate vs. $1^{\text {ry }}$ school & $-0.186,0.102$ & 0.56 & \multirow[t]{3}{*}{2.38} & \multirow[t]{3}{*}{0.069} \\
\hline & Illiterate vs. $2^{\text {ry }}$ school & $-0.292,0.006$ & 0.04 & & \\
\hline & Illiterate vs. University & $-0.358,-0.006$ & 0.043 & & \\
\hline \multirow[t]{3}{*}{ Body mass index } & Normal vs. underweight & $0.004,237$ & 0.04 & \multirow[t]{3}{*}{2.25} & \multirow[t]{3}{*}{0.11} \\
\hline & Normal vs. overweight & $-0.185,0.158$ & 0.88 & & \\
\hline & Underweight vs. over & $-0.320,0.052$ & 0.158 & & \\
\hline
\end{tabular}

\section{Discussion}

Investigating the effect of intestinal parasitic infection as a cause of IDA was necessary to help in directing interventions to face this problem especially in parasites endemic areas (Pullan and Brooker, 2008). The study revealed that Ancylostoma was a significant independent risk factor for IDA $(\mathrm{P}=0.017)$, associated with decreasing levels of ferritin in anemic children $(p=0.01)$. In concordance, association of IDA with helminthic parasite was documented (Stoltzfus, 1997; Crompton, 2000). Ancylostoma is one of the most important parasites that infect human (Stephenson, 1989). Iron deficiency anemia caused as a result of consumption of blood 
by Ancylostoma and coagulase released led to chronic intestinal blood loss (Ganz, 2006). Growing children have relatively poor iron stores and so they are more liable to IDA due to blood loss. The intensity of infection and actual Iron stores levels could affect the Progression to parasite induced iron deficiency anemia. Treatment of hookworm infection caused enhancement in iron status and improvement in work capacity (Stephenson, 1989).

\begin{tabular}{|c|c|c|c|c|}
\hline \multirow[t]{2}{*}{ Factors } & \multirow[t]{2}{*}{ OR } & \multicolumn{2}{|c|}{$95.0 \%$ Confidence Interval for OR } & \multirow[t]{2}{*}{ Sig. (P. value) } \\
\hline & & Lower Bound & Upper Bound & \\
\hline (Constant) & 0.133 & $-0.458-$ & 0.724 & 0.659 \\
\hline Age & 0.013 & $-0.001-$ & 0.028 & 0.065 \\
\hline Sex & $-0.067-$ & $-0.167-$ & 0.034 & 0.191 \\
\hline BMI & $-0.039-$ & $-0.110-$ & 0.032 & 0.279 \\
\hline rural & $-0.001-$ & $-0.099-$ & 0.097 & 0.986 \\
\hline Mother work & $-0.028-$ & $-0.133-$ & 0.077 & 0.596 \\
\hline Mother education & 0.037 & $-0.015-$ & 0.089 & 0.161 \\
\hline Income & 0.189 & 0.094 & 0.284 & 0.000 \\
\hline Meat/week & 0.151 & 0.077 & 0.224 & 0.000 \\
\hline Family members & $-0.107-$ & $-0.176-$ & $-0.039-$ & 0.002 \\
\hline A. lumcricoides & 0.159 & 0.050 & 0.269 & 0.004 \\
\hline E. vermicularis & 0.057 & $-0.042-$ & 0.156 & 0.261 \\
\hline A. duodenale & 0.188 & 0.034 & 0.341 & 0.017 \\
\hline H. nana & 0.004 & $-0.129-$ & 0.137 & 0.956 \\
\hline G. lamblia & 0.149 & 0.030 & 0.269 & 0.014 \\
\hline E. histolytica & 0.021 & $-0.083-$ & 0.125 & 0.692 \\
\hline
\end{tabular}

This study revealed that Ascaris was another significant predictor for IDA. This agreed with Osazuwa et al. (2011) and Ngui et al. (2012) who found significant association of Ascaris infection and anemia. It impairs the nutritional status of infected children and adolescences by increasing nutrient demands of the warm, anorexia and by blockage of the mucosa absorbing surface; iron absorption takes place in duodenum in infected patient (Jardim-Botelho et al, 2008). Also, Ascaris can cause Vitamin A mal absorption and lactose intolerance that affect children growth (Bethony et al, 2006). Treatment of Ascaris improved IDA (García-Leiva et al, 2008). But, Islek et al. (1993) didn't find associations between anemia and Ascaris.

The prevalence of $G$. intestinalis in Egypt was 11\% (el-Naggar et al, 2006), which showed that giardiasis had a significant independent effect on IDA. Giardiasis was associated with IDA, diminished iron absorption and decreased iron indices in infected (Abou-Shady et al, 2011; Ertan et al, 2002; Hussein et al, 2016). Its treatment improved hemoglobin level and all iron indices in iron deficiency anemia (Monajemzadeh,
2008; Prado et al, 2005). But, Al-Mekhlafi et al. (2005) found that treatment of asymptomatic giardiasis didn't affect hematological nor iron indices in children with IDA.

In the present study, age was not associated with IDA. This did not go with Habib et al. (2016) who found that anemia was associated with younger age due to iron deficiency. Infant and toddlers aged 13 to 36 years were more exposed to severe IDA than younger ones (Paoletti et al, 2014). Absence of the effect of age may be due to exclusion of infants less than 2 years in this study. Increased prevalence of intestinal parasites in older aged children could increase the possibility of IDA (Chang Cojulun et al, 2015).

In this study, low monthly income $(<1200$ LE) and eating meat less than twice weekly were risk factors for IDA as revealed via regression analysis. This agreed with Danquah et al. (2014) who found low house income was independently associated with low hemoglobin level. The low income limited access to foods rich in iron. Plant based diets (no meat and high phytic acids) in families with low income have lower level of iron bioavailability, and people following 
these diets are more prone to iron defeciency (National Health and Medical Research Council, 2014). Brussard et al. (1997) found a negative association between iron status and consuming vegetable protein. High number of family members was also independently associated with reduced hemoglobin level and IDA as revealed by regression analysis. Lower intake of iron in crowded families along with a higher rate of exposure to infections and intestinal helminthic infestations may be reasonable explanations (Curtale et al, 2000).

On the other hand, Abo-Madyan et al. (2004) Ezbet El-Bakly (Tamyia Center) AlFayoum Governorate carried out a field survey to assess the efficacy and safety of Mirazid in the treatment of human fascioliasis. Among 1019 individuals examined for parasitosis, the prevalence of fascioliasis was $1.7 \%$ and the geometric mean egg count was 33.2 eggs/gram stools. About $23.5 \%$ of patients were asymptomatic. The most frequent symptoms were abdominal dis and flatulence $(76.5 \%)$, right hypochondrial pain $(17.6 \%)$ and epigastric pain $(17.6 \%)$. igns were pallor $(52.9 \%)$, tender right hypochondrium $(23.5 \%)$ and tinge of jaundice (17.6\%). Others were S. mansoni (2.4\%), E. vermicularis $(2 \%)$, A. lumbricoides $(1.7 \%)$, H. nana (1.7\%), Taenia saginata $(0.3 \%)$.

Apart from Al-Fayoum, Morsy et al. (1991) in Qualyob City, Qualyobia Governorate examined two primary schools of 486 school children (6-12 years old) had pediculosis (16.04), schistosomiasis $(8.8 \%)$, E. histolytica $(7.81 \%)$, G. lamblia $(9.05 \%), T$. saginata $(0.41 \%)$, A. lumbricoides $(9.05 \%)$, E. vermicularis $(0.9 \%) \& H$. nana $(9.87 \%)$. The lice was $17.8 \%$ of total parasites detected. Autoinfection parasites were $43.02 \%$, those by skin penetration were $9.84 \%$, those by meat consumption were $0.45 \%$ and by other modes were $28.8 \%$. El-Shazly et al. (2006) in Dakahlia Governorate reported intestinal helminthes in a descending order of abundance were $S$. mansoni $(5.3 \%)$, Fasciola sp. (4.8\%), H. heterophyes (4.2\%),
H. nana (3.9\%), Trichostrongylus sp. (2.6\%), A. lumbricoides (1.8\%), Strongyloides stercoralis $(1.5 \%), H$. diminuta $(1.4 \%)$, Taenia saginata (1.1\%), E. vermicularis (by smear; $1.1 \%)$, T. trichura $(0.7 \%)$ and $A$. $d u$ odenale $(0.1 \%)$. Intestinal protozoa in an abundance descending order were Blastocystis hominis $(22.4 \%)$, G. lamblia (19.6\%), E. histolytica/E.dispar (19\%), Iodamoeba butschlii (16\%), Cryptosporidium parvum (14.3\%), E. coli $(9.7 \%)$, Isospora hominis (7.7\%), Endolimax nana (6.9\%), E. hartmani (5.9\%), Dientamoeba fragilis (5.1\%), Chilomastix mesnili (5.1\%), Trichomonas hominis (4.2\%), Cyclospora cayetanensis (4.2\%), Microsporidia spores (3.2\%), Enteromonas hominis $(1.9 \%)$ and Embadomonas intestinalis (1.3\%). Eraky et al. (2014) in Banha City in stool examination for intestinal parasites found in 157/530 (29.6\%) samples. G. lamblia cysts were the commonest one $(8.8 \%)$ followed by Entamoeba spp. cysts $(6.8 \%)$, E. vermicularis $(4.9 \%)$, helminth larvae (3.6\%), H. nana (2.8\%), $H$. diminuta $(2.1 \%)$, \& A. lumbricoides $(0.6 \%)$. Contaminated vegetable was lettuce $(46 \%)$, watercress $(41.3 \%)$, parsley $(34.3 \%)$, green onion $(16.5 \%)$, and leek $(10.7 \%)$. These results indicate a significant seasonal variation $(\mathrm{P}<0.05)$, with high prevalence in summer $(49 \%)$ and low in winter $(10.8 \%)$. Shehata and Hassanein (2015) in Alexandria reported 87/200 (43.5\%) mentally handicapped persons with parasitosis; $44.6 \%$ and $42.6 \%$ for non-institutionalized and institutionalized ones, respectively. They were $46.7 \%$ \& $38.5 \%$ males and females. Commonest were Cryptosporidium sp. (23.5\%), Microsporidia $(15 \%), G$. lamblia $(8.5 \%), D$. fragilis (8\%), C. cyatanensis (7.5\%), B. hominis (6.5\%), E. histolytica (5.5\%) and E. coli $(2.5 \%)$. I. belli and E. vermicularis were $1.5 \%$ and Iodamoeba butschlii was (1.0\%).

\section{Conclusion}

The data highlights the importance of $\mathrm{An}$ cylostoma, Ascaris and Giardia infections as risk factors for IDA among children. Ancylostoma and Giardia were associated with 
lower levels of ferritin in anemic children. Low family income, low frequency of eating meat and higher family size were additional important contributors for IDA. This would direct implementation of integrated health programs in areas of parasitosis to improve hygienic and public health aware-ness. Screening programs for parasites is a must. Nutrition education with iron rich supplement must be recommended in high risk groups. Health sectors must take an active role in improving healthy public policies to alleviate diseases related to poverty.

Conflict of interest: Authors declare no conflict of interest related to the manuscript contents, and the research was not funded.

\section{References}

Abdel-Rasoul, G, El Bahnasy, R, El Shazly, H, Gabr, H, Abdel-Aaty, N, 2015: Epidemiology of iron-deficiency anemia among primary school children (6-11years), Menoufia Governorate, Egypt. Menoufia Med. J. 28, 3:663-9

Abo-Madyan, AA, Morsy, TA, Motawea SM, Morsy, AT, 2004: Clinical trial of Mirazid in treatment of human fascioliasis, Ezbet El-Bakly (Tamyia Center) Al-Fayoum Governorate. J. Egypt. Soc. Parasitol. 34, 3: 807-18.

Abou-Shady, O, EI Raziky, M, Zaki, M, Mohamed, R, 2011: Impact of Giardia lamblia on growth, serum levels of zinc, copper, and iron in Egyptian children. Biol. Trace Elem. Res. 140, 1:1-6.

Al-Mekhlafi, MS, Azlin, M, Nor Aini, U, Shaik, A, Sa'iah, A, et al, 2005: Giardiasis as a predictor of childhood malnutrition in Orang Asli children in Malaysia. Trans. R. Soc. Trop. Med. Hyg. 99:686-91

Beard, JL, 2001: Iron biology in immune function, muscle metabolism and neuronal functioning. J. Nutr. 131, 2:S568-80.

Bethony, J1, Brooker, S, Albonico, M, Geiger, SM, Loukas, A, et al, 2006: Soil-transmitted helminth infections: Ascariasis, trichuriasis, and hookworm. Lancet 367:1521-32

Brooker, S, Kabatereine, NB, Smith, JL, Mupfasoni, D, Mwanje, MT, et al, 2009: An updated atlas of human helminth infections: The example of East Africa. Int. J. Hlth. Geogr. 8:42. doi: 10.1186/1476-072x-8-42

Brussard, JH, Brants, HAM, Bouman, M, Lowik, MRH, 1997: Iron intake and iron status among adults in the Netherlands. Eur. J. Clin. Nutr. 51:51-8.

Calis, JC, Phiri, KS, Faragher, EB, Brabin, BJ, Bates, I, et al, 2008: Severe Anemia in Malawian Children. N. Engl. J. Med. 358, 9:888-99. Chang Cojulun, A, Bustinduy, AL, Sutherland, LJ, Mungai, PL, et al, 2015: Anemia among children exposed to polyparasitism in coastal Kenya. Am. J. Trop. Med. Hyg. 93, 5:1099-105.

Crompton D, 2000: Public health impor-tance of hookworm disease. Parasitol. 121:S39-50.

Curtale, F, Abdel-Fatah, M, El-Shazly, H, Youssef-Shumy, M, El-Sahn, F, 2000: Anemia among young male workers in Alexandria, Egypt. East. Mediterr. Hlth. J. 6:1005-16.

Danquah, I, Gahutu, JB, Zeile, I, Musemakweri, A, Mockenhaupt, FP, 2014: Anaemia, iron deficiency and a common polymorphism of iron-regulation, TMPRSS6 rs855791, in Rwandan children. Trop. Med. Int. Hlth. 19, 1:117-22. Eden, AN, Sandoval, C, 2012: Iron deficiency in infants and toddlers in the United States. Pediatr Hematol. Oncol. 29:704-9

Elalfy, MS, Hamdy, M, Abdel Maksoud, S, 2012: Pattern of milk feeding and family size as risk factors for iron deficiency anemia among poor Egyptian infants 6 to 24 months old. Nutr. Res. 32:93-9.

El-Naggar, SM, el-Bahy, MM, Abd Elaziz, J, el-Dardiry, MA, 2006: Detection of pro-tozoal parasites in the stools of diarrhoeic patients using different techniques. J. Egypt. Soc. Parasitol. 36, 2:487-516.

El Shazly, AM, Awad, SE, Sultan, DM, Sadek, GS, Morsy, TA, 2006: Intestinal parasites in Dakahlia Governorate, with different techniques in diagnosing protozoa. J. Egypt. Soc. Parasitol. 36, 3:1023-34.

Eraky, MA, Rashed, SM, Nasr, MS, El-Hamshary, AM, Salah, El-Ghannam A, 2014: Parasitic contamination of commonly consumed fresh leafy vegetables in Banha, Egypt. Parasitol Res. 2014:613960. doi: 10.1155/2014/613960.

Ertan, P, Yereli, K, Kurt, O, BalciogluI, C, Onag, A, 2002: Serological levels of zinc, copper and iron elements among Giardia lamblia infected children in Turkey. Pedi. Int. 44:286-8

Ganz, T, 2006: Hepcidin and role in regulating systemic iron metabolism: Education Program. Hematology/American Society of Hematology, Garcia, LS, 2007: Diagnostic Medical Parasitology. $5^{\text {th }}$ ed. Washington, DC: ASM Press. García-Leiva, J, Barreto-Zuñiga, R, Estrad- 
as, J, Torre A, 2008: Ascaris lumbricoides and iron deficiency anemia. Am. J. Gastroenterol. 103:1051-2.

Haas, J. D, Brownlie, T, 2001: Iron deficiency and reduced work capacity: a critical review of the research to determine a causal relationship. J. Nutr. 131, 2:S676-90.

Habib, MA, Black, K, Soofi, SB, Hussain, I, Bhatti, Z, et al, 2016: Prevalence and predictors of iron deficiency anemia in children under five years of age in Pakistan: A secondary analysis of national nutrition survey data 2011-2012. PLoS One. 11(5):e015505. doi:10.1371/ journal.pone. 0155051

Hussein, ME, Zaki, MW, Ahmed, ASh, Almatary, MA, Nemr, AN, et al, 2016: Predominance of Giardia lamblia assemblage A among iron deficiency anaemic pre-school Egyptian children. Parasitol. Res. 115:1537-45.

Islek, I, Kuçukoduk, S, Cetinkaya, F, Gurses, N, 1993: Effects of Ascaris infection on iron absorption in children. Ann. Trop. Med. Parasitol. $87: 477-81$

Jardim-Botelho, A, Brooker, S, Geiger, SM, Fleming, F, Souza Lopes, AC, et al, 2008: Age patterns in under-nutrition and helminth infection in a rural area of Brazil: associations with ascariasis and hookworm. Trop. Med. Int. Hlth. 13:458-67.

Johnson-Wimbley, TD, Graham, DY, 2011: Diagnosis and management of iron deficiency anemia in the $21^{\text {st }}$ Century. Therap. Adv. Gastroenterol. 4:177-84.

Monajemzadeh, S, Monajemzadeh, M, 2008: Comparison of iron and hematological indices in Giardia lamblia infection before and after treatment in 102 children in Ahwaz, Iran. Med. Sci. Monit. 14, 1:CR19-23

Morsy, TA, Farrag, AM, Sabry, AH, Salama, MM, Arafa, MA, 1991: Ecto and endoparasites in two primary schools in Qualyob City, Egypt. J. Egypt. Soc. Parasitol. 21, 2:391-401.

National Health and Medical Research Council, 2014: Nutrient Reference Values for Australia and New Zealand including Recommended Dietary Intakes. Commonwealth of Australia, Canberra, Australia Available online: https:// www.nhmrc.gov.au/guidelines/publications/n35. Ngui, R, Lim, YA, Kin, L, Chuen, CS, Jaffar, S, 2012: Association between anemia, iron deficiency anemia, neglected parasitic infections and socioeconomic factors in rural children of West Malaysia. PLoS Negl. Trop. Dis. 6, 3: e1550

Nokes, C, Bundy, DAP, 1994: Does helminth infection affect mental processing and educational achievement? Parasitol Today 10: 14-8.

Osazuwa, F, Ayo, OM, Imade, P, 2011: A significant association between intestinal helminth infection and anaemia burden in children in rural communities of Edo State, Nigeria. Am. J. Med. Sci. 3, 1:30-4.

Paoletti, G, Paoletti, DL, Ritchey, AK, 2014: Severe Iron-Deficiency Anemia Still an Issue in Toddlers. Clin. Pediatr. 53, 14:1352-8.

Prado, MS, Cairncross, S, Strina, A, Barreto, ML, Oliveira-Assis, AM, et al, 2005: Asymptomatic giardiasis and growth in young children; A longitudinal study in Salvador, Brazil. Parasitol. 131:51-6.

Pullan, R, Brooker, S, 2008: The health impact of polyparasitism in humans: Are we underestimating the burden of parasitic diseases? Parasitol. 135:783-94

Rao, R, Georgieff, MK, 2001: Neonatal Iron Nutrition. Semin. Neonatol. 6, 5:425-35.

Shehata, AI, Hassanein, F, 2015: Intestinal parasitic infections among mentally handicapped individuals in Alexandria, Egypt. Ann. Parasitol. 61, 4:275-81.

Stephenson, LS, Kinoti, SN, Latham, MC, Kurz, KM, Kyobe, J, 1989: Single dose metrifonate or praziquantel treatment in Kenyan children. I. Effects on Schistosoma haematobium, hookworm, hemoglobin levels, splenomegaly, and hepatomegaly. Am. J. Trop. Med. Hyg. 41, 4: 436-44.

Stoltzfus, R, Chwaya, H, Tielsch, J, Schulze, K, Albonco, M, et al, 1997: Epidemiology of iron deficiency anemia in Zanzibari school children: Importance of hookworms. Am. J. Clin. Nutr. 65:153-9

UNICEF, 2002: Iron Deficiency Anemia Worldwide. Geneva, Switzerland

WHO, 1987: Technical Report Series 749: Prevention and Control of Intestinal Parasitic Infections, Geneva.

WHO, 2008: Worldwide prevalence of anemia 1993-2005: WHO Global Database on Anemia.

Wonke, B, Modell, M, Marlow, T, Khan, M, Modell, B, 2007: Microcytosis, iron deficiency and thalassaemia in a multi-ethnic community: A pilot study. Scand. J. Clin. Lab. Invest. 67:8795. 